THE RESPONSIBILITY OF THE PHILOSOPHER 



\section{THE RESPONSIBILITY OF THE PHILOSOPHER}

Edited with an Introduction by FRANCA D'AGOSTINI Translated by WILLIAM MCCUAIG 


\section{COLUMBIA UNIVERSITY PRESS}

Publishers Since 1893

New York Chichester, West Sussex

Originally published in Italian as Vocazione e responsabilità del filosofo Copyright (C) 2000 Gianni Vattimo

Translation copyright (C) 2010 Columbia University Press

\section{All rights reserved}

Library of Congress Cataloging-in-Publication Data

Vattimo, Gianni, 1936-

[Vocazione e responsabilita del filosofo. English]

The responsibility of the philosopher / Gianni Vattimo; edited with an introduction by Franca D'Agostini ; translated by William McCuaig.

p. $\mathrm{cm}$.

Includes bibliographical references and index.

ISBN 978-0-231-15242-6 (cloth : alk. paper)-ISBN 978-0-231-52712-5 (ebook)

1. Philosophy, Modern-2oth century. 2. Philosophy, Italian-2oth century. I. D'Agostini, Franca, 1952- II. Title.

B3654.V383V6313 2010

190-dc22 2010003075

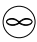

Columbia University Press books are printed on permanent and durable acid-free paper.

This book is printed on paper with recycled content. Printed in the United States of America

c 1098876554321

References to Internet Web sites (URLs) were accurate at the time of writing. Neither the author nor Columbia University Press is responsible for URLs that may have expired or changed since the manuscript was prepared. 